\title{
Micro- and Nano-Scale Characterization of Exceptionally Long Chrysotile Fibers from Val Malenco, Italy \\ RETO GIERÉ
}

University of Pennsylvania

Presenting Author: giere@sas.upenn.edu

This presentation will provide an overview of the serpentinite body in Val Malenco, Italy, and discuss results from a detailed micro- and nanoscale characterization of chrysotile fibers. The Malenco serpentinite occurs at the transition between the Penninic and Austroalpine domains of the Eastern Alps. It is the largest body of meta-ultramafic rocks in the Alps and has been quarried for use as a decorative and building stone since the Middle Ages.

Because of its geological and industrial importance, the serpentinite has been studied petrologically in great detail. The main minerals present in the regionally metamorphosed rock are antigorite, olivine, diopside, and magnetite. Depending on the distance to the Tertiary Bergell intrusion, the Malenco serpentinite also contains other minerals, including tremolite, titanian clinohumite, chlorite, talc, enstatite, anthophyllite, and spinel. One of the characteristics of the Malenco serpentinite is the occurrence of hydrothermal veins that host chrysotile asbestos, which has been mined extensively, beginning in the $19^{\text {th }}$ century and until 1975 . Because the extracted chrysotile fibers may reach 2 meters in length, the material was highly sought after for the manufacture of fire-proof fabrics (including tablecloths) and wicks.

In this study, chrysotile from a quarry near Franscia in Val Malenco has been characterized in detail by using X-ray powder diffractometry and powder FTIR spectroscopy, as well as scanning electron microscopy (SEM) and transmission electron microscopy (TEM), both combined with energy-dispersive X-ray (EDX) spectroscopy. The investigated chrysotile contains up to $6.5 \mathrm{wt} \% \mathrm{FeO}$ and up to $4.4 \mathrm{wt} \% \mathrm{Al}_{2} \mathrm{O}_{3}$. Associated with the chrysotile are sub- $\mu \mathrm{m}$-sized magnetite particles. The examination by TEM revealed that the chrysotile fibers consist of bundles of individual fibers, which range approximately from 50 to $300 \mathrm{~nm}$ in length and 18 to $31 \mathrm{~nm}$ in width (average width: $21.6 \pm 1.5 \mathrm{~nm}$; $n=125$ ). These nano-sized elongate mineral particles (EMPs) are highly crystalline. The presentation will highlight the size distributions and morphological details of the EMPs and explore how they bundle together in a sub-parallel fashion to form the exceptionally long chrysotile fibers. 